\title{
Using an ACAdemic Plan Model to Analyze Canadian ENGINEERING LEADERSHIP CURRICULUM
}

\author{
Mike Klassen ${ }^{1}$ and John Donald ${ }^{2}$ \\ ${ }^{1}$ Institute for Leadership Education in Engineering, Faculty of Science and Engineering, University of Toronto \\ ${ }^{2}$ School of Engineering, University of Guelph \\ Corresponding Author E-mail: mike.klassen@utoronto.ca
}

\begin{abstract}
This paper analyzes engineering leadership curriculum in Canadian universities. Using an adapted framework for curriculum development, we analyze key documents for six engineering leadership programs in six different universities. Findings show a wide range of purposes, content and sequencing, with a common core of instructional processes and resources. We explore how accreditation, labour markets, internal resources and relationships with business schools shape curriculum decisions. Future work will explore deeper connections between influences and the curriculum, and comparisons between Canada and other jurisdictions.
\end{abstract}

Keywords: engineering leadership, curriculum, curriculum development process, academic plan

\section{INTRODUCTION}

The concept of engineering leadership in industry contexts is nothing new - since the early days of professionalization, influential engineers have led companies and organizations. What is new is the idea that universities have a role to play in cultivating leadership capabilities, over and above the core scientific and technical knowledge base that is the centerpiece of engineering education. Our interest in this paper is to develop a systematic approach to capturing the nature, content and context of discrete programs that explicitly seek to develop 'engineering leadership'. Analyzing the results of this approach can lead to greater understanding and guidance to those developing relevant leadership curriculum in engineering schools. We take a wide view of what counts as leadership, including both process-oriented and position-oriented definitions. While the quest for an agreed upon definition is a noble one, it is not our focus here. In seeking to understand the content (what is taught) in engineering leadership programs, we look to established higher education scholars, Lattuca and Stark [11, p. 229], for a definition of curriculum development that emphasizes intentional decision making:
"Curriculum development is a process by which an instructor or group of instructors solves the complex problem of constructing a learning plan by making a series of decisions."

To further narrow our scope in this paper, we consider engineering leadership in Canada only. There is an active initiative to identify and support the growth of engineering leadership programs in universities that signals the growth in interest and concrete programming [14].

\section{LITERATURE REVIEW}

Two main types of studies have been presented or published on the topic of engineering leadership education in North America. The first type includes individual program descriptions, and there are significantly more of these. These studies usually come in the form of conference papers, which explain a single course, program, degree or even an individual learning activity in some detail, with varying degrees of assessment reported, and sometimes more systematic program evaluation [5,7-8,12-13,17]. These studies provide a level of depth and detail that can be of significant value to peer practitioners looking to learn about each other's work. However, they vary widely in their structure and emphasis, and rarely apply an explicit conceptual framework, which limits theoretical generalization of findings.

The second type of study, of which there are fewer, is comparative study of several universities to identify patterns, types and interesting differences in programmatic delivery $[6,9,15,16]$. These tend to have less depth, and many have focused heavily on the United States because of its higher concentration of well-resourced, established engineering leadership programs. A few studies have included Canadian programs $[9,16]$, but usually they are a minority in the wider sample. Overall, these studies have focused mainly on higher level characteristics such as leadership philosophy [9], mission [16], and structure of delivery $[9,11,15]$. 
We note an absence of comparative studies that look at the actual content of the curriculum in engineering leadership programs in different universities in Canada. This sets up our two research questions for this paper: (1) What are the current curriculum practices being implemented in Canada? and (2) To what extent can a formal curriculum development framework help us categorize and compare different approaches?

\section{METHODOLOGY}

We have chosen to use Lattuca and Stark's academic plan model [11] because it is a well-established framework built on extensive literature review of curriculum in higher education. The framework, presented in Figure 1, captures the external influences (e.g. market forces, accreditation agencies, donors/funders) and the internal influences (e.g. faculty mission/vision; resources; individual faculty passion; student characteristics) shaping the curriculum as well as the seven elements of the academic plan itself (i.e. purpose, content, sequence, learners, instructional processes, instructional resources, and evaluation).

We selected six examples of Canadian engineering leadership "curriculum" to have a mix of geography (1 British Columbia, 1 Alberta, 3 Ontario, 1 Prince Edward Island); content focus (personal, team and organizational leadership); delivery context (graduate and undergraduate) and institutional context (large and small universities, research and teaching intensive). Our goal for this study is to refine and adapt the academic plan to the specific context of engineering leadership education in universities, so this sample is not meant to be 'representative' in a statistical sense. Instead we aimed for diversity and richness in our sample, without it being so idiosyncratic that we would not find any patterns.

To carry out the analysis we examined publicly available program descriptions (syllabi, program outlines and websites, strategic plans), conference papers and grey literature collected at the National Initiative on Capacity Building and Knowledge Creation for Engineering Leadership (NICKEL) conferences in 2016 and 2017 [14].

Our analysis involved iterating between Lattuca and Stark's broad categories of academic plans and key influences, and the concrete examples of these categories in our qualitative data. An example is shown in Table 1:
Table 1: Example development of categories.

\begin{tabular}{|l|l|}
\hline \multicolumn{2}{|c|}{ Iteration 1 } \\
\hline \multicolumn{1}{|c|}{$\begin{array}{c}\text { Lattuca \& Stark } \\
\text { Definition [11, p. 4] }\end{array}$} & \multicolumn{1}{c|}{$\begin{array}{c}\text { Our questions to } \\
\text { operationalize in EL }\end{array}$} \\
\hline $\begin{array}{l}\text { Sequence: } \\
\text { “Arrangement of the } \\
\text { subject matter and } \\
\text { experiences intended } \\
\text { to lead to specific } \\
\text { outcomes for } \\
\text { learners” }\end{array}$ & $\begin{array}{l}\text { What is the order of content } \\
\text { delivery? } \\
\text { How is the content parsed? } \\
\text { To what extent is it } \\
\text { cumulative/isolated/parallel? }\end{array}$ \\
\hline $\begin{array}{l}\text { Examples from } \\
\text { document analysis }\end{array}$ & $\begin{array}{l}\text { Categories emerging from } \\
\text { multiple examples }\end{array}$ \\
\hline $\begin{array}{l}\text { Week-by-week topic } \\
\text { modules \& } \\
\text { assessment dates } \\
\text { (several pages for } \\
\text { each case). }\end{array}$ & $\begin{array}{l}\text { (1) Projects } \\
\text { a - Single course-long; } \\
\text { b - multiple, short, series } \\
\text { c - capstone } \\
\text { (2) Personal then } \\
\text { organizational leadership } \\
\text { content } \\
\text { (3) Theory then practice/ } \\
\text { application }\end{array}$ \\
\hline \multicolumn{2}{|l}{} \\
\hline
\end{tabular}

In the first iteration, we operationalized the categories by posing a series of questions to enable us to apply the Lattuca and Stark definition to the curriculum documents we were analyzing. When reviewing documents for each program, we captured as much detail for each question as possible. In the second iteration, we grouped common themes and concepts under each category to increase our level of abstraction. For example, when operationalizing "sequence" within the academic plan, we first extracted the exact day-by-day schedule of topics/ lessons from each program, and then looked for patterns such as "from theory to practice" or "iterative reflection based on experiential learning". We then refined these generalized codes for each of the seven elements of the academic plan.to make comparison easier.

We undertook this iterative process for both the curriculum itself and for the internal and external influences. The final stage of our analysis was to look for connections between the influences and the curriculum in a given university, and to look across universities for patterns in how certain constellations of influences were shaping similar or different curriculum decisions. For reasons of space, in this paper we present only a brief summary of our analysis of the influences.

\section{RESULTS AND FINDINGS}

The academic plan model [11] provides an excellent framework for analyzing the engineering leadership curriculum selected from the six Canadian institutions. The 
detailed findings for the seven elements of Lattuca and Stark's model [11] are summarized in Appendix A and reported below. For each element, we briefly summarize a simplified definition, then summarize our findings.

1. Purposes: "Knowledge, skills and attitudes to be learned” [11, p. 4]. We chose examples of curriculum that sought to intentionally develop leadership competencies in engineering students. We found programs saw their purpose as providing a varying base of theory, with major themes of personal leadership and leadership in the organizational context. We also found an emphasis on providing experiential opportunities such as projects, and observational learning through case studies. Different programs emphasized leadership in different contexts: in life, in teams, in the workplace and in student organizations.

2. Content: "Subject matter selected to convey specific knowledge, skills, and attitudes” [11, p.4]. Many of the examples anchored their curriculum in a particular leadership model or framework: The University of Guelph course leveraged the "Leadership Challenge" framework of Kouzes and Posner [10]; Cameron and Quinn's “Competing Values Framework” [1] was used at both the University of Toronto and the University of Guelph; and Western University emphasized the leader character model [4]. Overall, we found a strong content focus on personal leadership models and personality type inventory assessments were commonly applied. Most offerings also focus on teams to some extent. Management of various forms (personal, project, change, etc.) was the most densely populated content domain from across all six examples. Finally, reflective practice was a key skill taught in more than half of the examples, which aligns well with requirements for engineering design.

3. Sequence: “An arrangement of the subject matter and experiences intended to lead to specific outcomes for learners" [11, p.4]. Sequence was difficult to generalize as the cases had very different designs and structures. The co-curricular undergraduate programs exhibit a tiered structure and iterative sequence whereby students needed to obtain certain experience before progressing, and content was arranged to iteratively build on previous learning. Elective courses tended to start with personal and progress to organizational leadership, and start with theory before shifting to practice. Class projects were structured in two ways: either linking the leadership content to a semester long activity, or delivering theory first followed by a capstone type project at the end. There were a variety of approaches to the sequence of delivery with no one method dominating the approach. A more in-depth analysis of a wider set of examples is needed to more clearly identify patterns in sequencing.

4. Learners: "How the plan will address a specific group of learners” [11, p. 5]. Student backgrounds varied widely from undergraduate to graduate student, in some cases including students with industry experience. With the exception of the mandatory design course, it is likely that student motivation toward leadership is high, as students self-selected or entered a competitive process to access the leadership curriculum. The co-curricular programs studied use “elite” branding to attract appropriate learners, including applications, interviews and levels of achievement labelled “Excellence”. For all programs, leadership is offered to students from multiple disciplines of engineering, but nowhere are students from outside engineering included. Learners have little formal background in leadership training and programming takes this into account. On the other hand, the learners have a breadth of experiences that can be leveraged as resource in their own right, if recognized by the instructors.

5. Instructional Resources: "the materials and settings to be used in the learning process” [11, p. 5]. Class size is generally small with the largest documented class size only 35 students, which allows for discussion and interaction. Offerings are mostly delivered in lecture rooms supported by other types of configurations, such as design labs or configurable discussion space. Readings are mostly drawn from popular business publishers like Harvard Business Review and texts tend to be popular business texts such as The 7 Habits of Highly Effective People [3], The Leadership Challenge [10], and Crucibles of Leadership [18]. These resources are grounded in extensive experience or research, but practical so that engineering students can concretely grasp what they mean. In most cases, external industry leaders or engineering case studies are other key resources that foreground the engineering context of leadership learning.

6. Instructional Processes: "The instructional activities by which learning may be achieved" [11, p.5]. Lectures are the most common method of delivery with reinforcement through discussion groups and reflection. Case studies feature prominently in courses where organizational leadership is emphasized. Projects often form a backbone for application of concepts, and working in teams and interacting with industry and leaders is also a common feature. There are often numerous assessment points, with exams only used in a minority of cases. Reflection journals or papers, self and peer evaluation, leadership or design projects, presentations and participation in discussion groups 
are all very common. Assessment is thus aligned with the experiential philosophy that is prominent in the engineering leadership courses. In addition, there is frequent use of the dual role of delivery and assessment in most cases (e.g. reflection, projects, and presentations). For example, presentations have the students practicing and being evaluated on a leadership skill. It is also a method of delivery of some material as other students learn from the varied material in their peers' presentations.

7. Assessment and Evaluation: "Enhancements to the plan based on experience and evaluation” [11, p. 5] We found limited information regarding assessment and evaluation of the curriculum in our data. Beyond the assumed student assessment of teaching and student participant feedback, accreditation (graduate attributes) is explicitly referenced in the undergraduate course offerings. The co-curricular program at $\mathrm{U}$ of $\mathrm{T}$ uses midpoint, endpoint and 4 month follow up feedback surveys. More direct discussions with instructors would be required to unpack how the leadership curriculum itself has changed based on assessment and evaluation.

The detailed information summarized above and documented in Appendix A directly captures the application of the academic plan in the local educational environment. During our review of curriculum, websites and other related documents, we also captured insights into the impact of the sociocultural context by examining the internal and external influences of institutional environment. Two key external influences were the relevance of leadership in the labour market; and the impact of engineering accreditation criteria. The external influence of the market manifested as recognition that leadership development is linked with students' ability to find employment and contribute more fully to organizations in industry. Sometimes this was framed as 'necessary' and part of engineering; other times framed as a 'differentiator' for getting engineering jobs in a tough job market. The external influence of accreditation shows up when engineering leadership instructors align it with key graduate attribute outcomes (e.g. Professionalism, Communication, Teamwork, Ethics \& Equity) [2, p. 1314]. This becomes salient when leadership learning is offered as part of required courses, such as engineering design courses, or elective courses that fill complementary studies requirements.

Two key internal influences that stood out were the financial resources available for the leadership programming; and the relationships between the engineering school in question and the business school at the university. Financial resources shape curriculum decisions because revenue from student enrolment, particularly in professional master's programs, can both justify and drive the creation of engineering leadership courses at the graduate level. Alternatively, resources from donors can directly shape the creation of programs (e.g. Chair in Engineering Leadership \& Innovation at Western). Also, where experiential learning and student experience is a crucial high-level goal in a school's strategic plan, this can lead to budgets being available from Dean's Office (e.g. University of Calgary). Inter-faculty relationships shape curriculum decisions particularly when business schools offer leadership teaching to engineering students. A strong link with the business school provides opportunities to offer curriculum that can be packaged in a unique way by leveraging resources and expertise that may not be available in engineering. For example, at UBC this led to a jointly offered full graduate program (Master of Engineering Leadership) and at Western resulted in a certificate made available to undergraduate students.

\section{DISCUSSSION}

The academic plan model enabled a structured approach to reviewing curriculum examples from six Canadian engineering institutions. The findings show a wide variety of approaches, materials and resources are utilized in engineering leadership curricula. Clearly, program designers and instructors understand engineering leadership in a myriad of different ways, and this is reflected in the content they select and the specific texts, theories and frameworks they use to communicate that to students. These are signs that this is a nascent field, and it also explains why faculty and staff who are active in this space are keen to connect, share resources and experiences, and learn from each other.

The findings point to a number of features that are commonly emphasized in the engineering leadership curriculum. These include:

- Small class sizes comprised of a variety of engineering disciplines

- A preference for experiential approaches, such as leadership or design projects

- Working in teams.

- A foundational grounding in personal values and selfleadership

- The use of textbooks that provide practical examples from industry

- Exposure to industry leaders in the classroom setting

- An emphasis on the positive relations of leadership to a successful job/career

- A much wider range of delivery and assessment methods than traditional engineering courses

The full analytic power of the academic plan in sociocultural context comes from relating the findings about internal and external influences to the findings about the engineering leadership curriculum itself. One pattern 
observed is that programs that included faculty members from the business school emphasized organizational leadership and management in workplace contexts, using case studies to teach and assess student learning. On the other hand, initiatives that were largely endogenous to engineering instructors themselves tend to emphasize personal leadership in life and school contexts, using team projects and reflective activities to support student learning. A crucial finding is that the inclusion of explicit engineering leadership curriculum is highly dependent on whether external sources (e.g. donors, industry sponsors, industry driven market for graduate students) can bring resources, both financial and symbolic, to support this development.

Even with a sample of only six cases, and data limited to document analysis, we were able to discern similarities and differences and gain insight into the role of internal and external influences. This is a solid foundation for future comparative analysis of engineering leadership programs that can bring value to researchers and instructors. Future research can expand in breadth and depth with more examples of different programs and new sources of data. This will help expand the range of possibilities for each category in our table in Appendix A, and ultimately, we can envision developing a large-scale survey to make statistical claims about the prevalence of different practices.

Ultimately, the language and structure developed here provides a stronger basis for mutual understanding and comparison among peers who are leading these programs. Also, the academic plan's focus on intentional decisions about curriculum development lends itself well to informing future program development. By connecting decisions about curriculum content, sequence, learners and instructional processes with a clearer appreciation of external forces, internal resources and organizational constraints, program developers can have better chances of successfully introducing engineering leadership to their colleagues.

\section{CONCLUSIONS}

In this study, we set out to examine the questions (1) What are the current curriculum practices being implemented in Canada? and (2) To what extent can a formal curriculum development framework help us categorize and compare different approaches? By applying the academic plan model to engineering leadership curriculum at six Canadian universities, we have developed a preliminary taxonomy that is specific to the engineering leadership curriculum. We applied this to six different cases from different universities.

Using the themes/question we were able to discern a number of common approaches and observe a variety of differences in the engineering leadership curriculum in a structured and detailed manner. The process also allowed us to unpack internal and external influences on the development and implementation of engineering curriculum that will be useful to those looking to start, revise or expand their engineering leadership offerings.

This paper showed that a formal curriculum development framework does help categorize and compare different approaches. We acknowledge the limits in both the breadth and overall size of the selected cases and the limited level of detail in our data, and yet a novel analysis was still possible.

Future work will apply the model more broadly in Canada to validate and refine the taxonomy, including a full analysis of internal and external influences to the same detail as we present here for the elements of the curriculum itself. There is also scope for explicit comparisons between Canada and the United States, where there are fundamental differences in institutional cultures and external influences, which can illustrate how context shapes curriculum decisions.

\section{Acknowledgements}

This work has grown out of interaction with a number of engineering leadership educators, and in particular those that have participated in the National Initiative on Capacity Building and Knowledge Creation for Engineering Leadership (NICKEL) conferences in 2016 and 2017.

The authors would like to thank individuals who shared curriculum documents for the six examples included in the study.

\section{References}

[1] Kim S. Cameron and Robert E. Quinn, Diagnosing and changing organizational culture: Based on the competing values framework. John Wiley \& Sons, 2005.

[2] Canadian Engineering Accreditation Board, 2016 Accreditation Criteria and Procedures, Ottawa, ON: Engineers Canada, 2016, 121 pp.

[3] Stephen R. Covey, The 7 habits of highly effective people: Powerful lessons in personal change. Simon and Schuster, 2013.

[4] Mary Crossan, Daina Mazutis, Gerard Seijts, and Jeffrey Gandz, "Developing leadership character in business programs," Academy of Management Learning \& Education, vol. 12, no. 2, pp. 285-305, 2013.

[5] Roger Gonzalez, Richard Schoephoerster, and Jessica Townsend. "Engineering Leadership: A New Engineering Discipline.” in Proc. ASEE Annual Conference and Exposition, ASEE15, (Seattle, WA; June 2015), 12 pp., 2015. 
[6] Ruth Graham, Edward Crawley, and Bruce R. Mendelsohn. Engineering leadership education: A snapshot review of international good practice, Cambridge, MA: Bernard M Gordon MIT Engineering Leadership Program, 2009.

[7] Minha R. Ha. "Experiential learning in leadership development: Select program at McMaster University," in Proc. Canadian Engineering Education Association Conf., CEEA13, (Montreal, QC; June 2013), 2013.

[8] Amy Hsiao, "Developing engineering managers: The master of engineering management program at Memorial University of Newfoundland," in Proc. of the Canadian Engineering Education Association Conf., CEEA13, (Montreal, QC; June 2013), 2013.

[9] Mike Klassen, Doug Reeve, Cindy Rottmann, Robin Sacks. "Charting the landscape of engineering leadership education in North American universities." in Proc. ASEE Annual Conference and Exposition, ASEE16, (New Orleans, LA; June 2016), 16 pp., 2016.

[10] James M. Kouzes and Barry Z. Posner, The leadership challenge: how to make extraordinary things happen in organizations, Jossey-Boss, 2012 (5th ed.)

[11] Lisa R. Lattuca and Joan S. Stark. Shaping the college curriculum: Academic plans in context. San Francisco, CA: Jossey-Bass, 2009.

[12] Richard H. McCuen, "A course on engineering leadership," Journal of Professional Issues in Engineering Education and Practice, vol. 125, no. 3, pp. 79-82, 1999.
[13] Dena E. McMartin, "Service Learning and Team Work Elements of Leadership," in Proc. of the Canadian Engineering Education Association Conf., CEEA13, (Montreal, QC; June 2013), 2013.

[14] National Initiative on Capacity Building and Knowledge Creation for Engineering Leadership. http://www.engineeringleaders.ca/nickel/ Accessed January 03, 2018.

[15] Joshua C. Palmer, Kenneth D. Birchler, Joseph D. Narusis, Rhonda K. Kowalchuk, and Bruce DeRuntz. "LEADing The Way: A Review of Engineering Leadership Development Programs," in Proc. ASEE Annual Conference and Exposition, ASEE16, (New Orleans, LA; June 2016), 15pp., 2016.

[16] Robin Paul, Lynn G. Cowe Falls. "Engineering Leadership Education: A Review of Best Practices." in Proc. ASEE Annual Conference and Exposition, ASEE15, (Seattle, WA; June 2015), 10 pp., 2015.

[17] Richard Schuhmann, Andrew Michael Erdman, Jack Matson, Dena Lang, Jeffrey Soper, and Donald Horner Jr. "Engineering Leadership Education - The Path Forward." in Proc. ASEE Annual Conference and Exposition., ASEE15, (Seattle, WA; June 2015), 19 pp., 2015.

[18] Robert J. Thomas, Crucibles of leadership: How to learn from experience to become a great leader. Harvard Business Press, 2008.

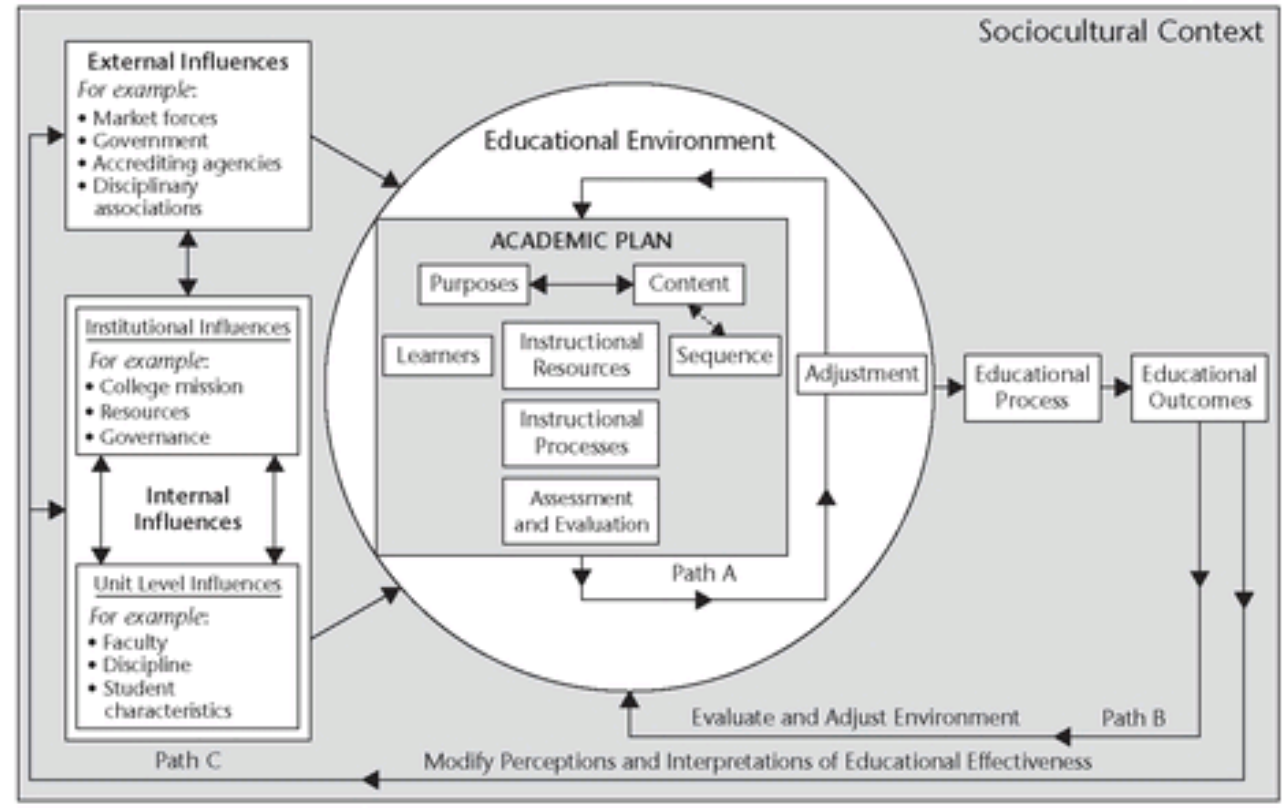

Figure 1: Lattuca and Stark's Academic Plans in Sociocultural Context [11, p. 5]. 
APPENDIX A: Comparison of Canadian Engineering Leadership Curriculum using the Academic Plan Model [11]

\begin{tabular}{|c|c|c|c|c|c|c|}
\hline Institution & Calgary & Toronto & UPEI & Western & UBC & Guelph \\
\hline Unit of Analysis & Co-curricular & Co-Curricular & Design Course & Leadership Course & Leadership Course & Leadership Course \\
\hline Academic Level & Undergraduate & Undergraduate & Undergraduate & Undergraduate & Graduate & Graduate \\
\hline \multicolumn{7}{|l|}{ 1. Purpose } \\
\hline $\begin{array}{l}\text { Leadership } \\
\text { Focus }\end{array}$ & Personal & $\begin{array}{l}\text { Personal } \\
\text { Organizational }\end{array}$ & $\begin{array}{l}\text { Team } \\
\text { Interpersonal }\end{array}$ & $\begin{array}{l}\text { Personal } \\
\text { Organizational }\end{array}$ & Organizational & $\begin{array}{l}\text { Personal } \\
\text { Team }\end{array}$ \\
\hline Context & Team; Life & Student Club & Team & Workplace & Workplace & Workplace; Life \\
\hline $\begin{array}{l}\text { Educational } \\
\text { Philosophy }\end{array}$ & $\begin{array}{l}\text { Theory \& } \\
\text { Experiential }\end{array}$ & $\begin{array}{l}\text { Theory \& } \\
\text { Experiential }\end{array}$ & Experiential & Theory \& Observational & $\begin{array}{l}\text { Theory \& } \\
\text { Observational }\end{array}$ & $\begin{array}{l}\text { Theory, Experiential \& } \\
\text { Observational }\end{array}$ \\
\hline \multicolumn{7}{|l|}{ 2. Content } \\
\hline $\begin{array}{l}\text { Organizational } \\
\text { (Org.) } \\
\text { frameworks } \\
\end{array}$ & Unclear & $\begin{array}{l}\text { Org. culture; } \\
\text { Competing } \\
\text { values } \\
\end{array}$ & Unclear & Vision \& Org. Change & Org. learning & Competing values \\
\hline $\begin{array}{l}\text { Personal } \\
\text { leadership }\end{array}$ & $\begin{array}{l}\text { Emotional } \\
\text { intelligence }\end{array}$ & $\begin{array}{l}\text { Leadership } \\
\text { crucibles; } \\
\text { Values } \\
\end{array}$ & $\begin{array}{l}\text { Servant \& authentic } \\
\text { leadership }\end{array}$ & Leader character & Personal ethics & Kouzes and Posner \\
\hline $\begin{array}{l}\text { Personality } \\
\text { type/inventories }\end{array}$ & Unclear & Unclear & Social Styles & $\begin{array}{l}\text { Communication \& } \\
\text { Leadership styles }\end{array}$ & Unclear & Social styles \\
\hline $\begin{array}{l}\text { Leadership } \\
\text { Skills }\end{array}$ & $\begin{array}{l}\text { Reflective } \\
\text { practice }\end{array}$ & $\begin{array}{l}\text { Active } \\
\text { listening }\end{array}$ & Reflective practice & Unclear & Unclear & Reflective practice \\
\hline Teams & $\begin{array}{l}\text { Managing } \\
\text { teams } \\
\text { Conflict }\end{array}$ & Unclear & Team roles & Workplace Conflict & Managing teams & Intercultural leadership \\
\hline $\begin{array}{l}\text { Management } \\
\text { (Mgmt.) }\end{array}$ & $\begin{array}{l}\text { Time \& } \\
\text { Project } \\
\text { Mgmt.; } \\
\text { Strategic } \\
\text { Planning }\end{array}$ & $\begin{array}{l}\text { Change } \\
\text { Mgmt. } \\
\text { Culture setting }\end{array}$ & $\begin{array}{l}\text { Org. structure } \\
\text { Client mgmt. } \\
\text { Innovation }\end{array}$ & $\begin{array}{l}\text { Supervision vs. } \\
\text { management vs. } \\
\text { Leadership Mentoring }\end{array}$ & $\begin{array}{l}\text { Change mgmt.; } \\
\text { Manger roles to } \\
\text { motivate and get } \\
\text { results; }\end{array}$ & $\begin{array}{l}\text { Time \& Project Mgmt. } \\
\text {; Strategic Planning }\end{array}$ \\
\hline \multicolumn{7}{|l|}{ 3. Sequence } \\
\hline & $\begin{array}{l}\text { Tiered } \\
\text { program } \\
\text { structure; } \\
\text { Personal -> } \\
\text { Team. }\end{array}$ & $\begin{array}{l}\text { Iterative } \\
\text { sequence } \\
\text { centered on } \\
\text { Personal-Org. }\end{array}$ & $\begin{array}{l}\text { Course long design } \\
\text { project } \\
\text { Organizational -> } \\
\text { Team }\end{array}$ & $\begin{array}{l}\text { Personal -> team -> Org. } \\
\text { Prerequisite courses in } \\
\text { business. }\end{array}$ & $\begin{array}{l}\text { Theory -> practice } \\
\text { End of course } \\
\text { project/capstone }\end{array}$ & $\begin{array}{l}\text { Single course-long } \\
\text { interview project. } \\
\text { Personal-> Org. with } \\
\text { iterative reflection. }\end{array}$ \\
\hline
\end{tabular}




\begin{tabular}{|c|c|c|c|c|c|c|}
\hline \multicolumn{7}{|l|}{ 4. Learners } \\
\hline Degree & Undergraduate & Undergraduate & Undergraduate & Undergraduate & Graduate & Graduate \\
\hline Course Type & $\begin{array}{l}\text { Self-select (yr } \\
1 \text { to yr } 4)\end{array}$ & $\begin{array}{l}\text { Self-select (yr } \\
2 \text { to yr } 4)\end{array}$ & Mandatory & Elective & Mandatory & Elective \\
\hline $\begin{array}{l}\text { Discipline of } \\
\text { engineering }\end{array}$ & Mixed & Mixed & Sustainable design & Mixed & Mixed & Mixed \\
\hline $\begin{array}{l}\text { Experience } \\
\text { requirements }\end{array}$ & $\begin{array}{l}\text { Tiered } \\
\text { students }-3^{\text {rd }} \\
\text { level mentor } \\
2^{\text {nd }} \text { level }\end{array}$ & $\begin{array}{l}\text { Student club } \\
\text { leadership }\end{array}$ & $\begin{array}{l}\text { Tiered students - yr4 } \\
\text { "mentor" yr3 }\end{array}$ & Limited work experience & $\begin{array}{l}5 \text { years industry } \\
\text { experience (target) }\end{array}$ & $\begin{array}{l}\text { Limited work } \\
\text { experience }\end{array}$ \\
\hline $\begin{array}{l}\text { Special } \\
\text { recognition }\end{array}$ & $\begin{array}{l}\text { Co-curricular } \\
\text { record }\end{array}$ & $\begin{array}{l}\text { Application } \\
\text { process }\end{array}$ & & Optional certificate & & \\
\hline \multicolumn{7}{|c|}{ 5. Instructional Resources } \\
\hline Class Size & Variable & $10-12$ & $20-25$ & Unclear & 35 & $15-20$ \\
\hline Classroom Type & $\begin{array}{l}\text { Classroom/ } \\
\text { workshop }\end{array}$ & $\begin{array}{l}\text { Meeting } \\
\text { boardroom }\end{array}$ & Blend lecture + lab & Unclear & Lecture room & Reconfigurable \\
\hline Texts & $\begin{array}{l}\text { Accessible, } \\
\text { personal }\end{array}$ & $\begin{array}{l}\text { Accessible, } \\
\text { personal } \\
\text { Selected } \\
\text { readings }\end{array}$ & unclear & $\begin{array}{l}\text { Case studies (practical, } \\
\text { business context) } \\
\text { Selected readings }\end{array}$ & $\begin{array}{l}\text { Case studies } \\
\text { (practical, business } \\
\text { context) } \\
\text { Selected readings }\end{array}$ & $\begin{array}{l}\text { Accessible, personal } \\
\text { Selected readings }\end{array}$ \\
\hline External & $\begin{array}{l}\text { Community } \\
\text { partners }\end{array}$ & $\begin{array}{l}\text { Industry } \\
\text { leader; Ext. } \\
\text { facilitators }\end{array}$ & $\begin{array}{l}\text { Industry partner } \\
\text { Course instructor as } \\
\text { team CEO }\end{array}$ & Industry guest speakers & $\begin{array}{l}\text { Industry involved in } \\
\text { development }\end{array}$ & $\begin{array}{l}\text { Industry leaders } \\
\text { Community leaders }\end{array}$ \\
\hline \multicolumn{7}{|l|}{$\begin{array}{l}\text { 6. Instructional } \\
\text { Processes }\end{array}$} \\
\hline Delivery & $\begin{array}{l}\text { Events } \\
\text { Workshops } \\
\text { Reflection } \\
\text { Community } \\
\text { project roles }\end{array}$ & $\begin{array}{l}\text { Workshops } \\
\text { Change } \\
\text { Projects } \\
\text { Discussion } \\
\text { Groups } \\
\end{array}$ & $\begin{array}{l}\text { Lectures } \\
\text { Design Project } \\
\text { Instructor-team } \\
\text { meetings }\end{array}$ & $\begin{array}{l}\text { Lectures } \\
\text { Case studies } \\
\text { Discussion groups } \\
\text { Student presentations }\end{array}$ & $\begin{array}{l}\text { Lectures } \\
\text { Case studies } \\
\text { Student } \\
\text { presentations } \\
\text { Leadership Project } \\
\end{array}$ & $\begin{array}{l}\text { Lectures } \\
\text { Discussion groups } \\
\text { Industry speakers } \\
\text { Leadership Project } \\
\text { Student presentations }\end{array}$ \\
\hline $\begin{array}{l}\text { Student } \\
\text { Assessment }\end{array}$ & $\begin{array}{l}\text { Self \& Peer } \\
\text { Evaluation } \\
\text { Presentation } \\
\text { Reflection } \\
\text { modules }\end{array}$ & $\begin{array}{l}\text { Peer } \\
\text { Evaluation } \\
\text { In process } \\
\text { facilitator } \\
\text { feedback }\end{array}$ & $\begin{array}{l}\text { Self \& Peer Evaluation } \\
\text { Presentation } \\
\text { Reflection papers }\end{array}$ & $\begin{array}{l}\text { Presentation } \\
\text { Class participation } \\
\text { Final paper/report }\end{array}$ & $\begin{array}{l}\text { Exams } \\
\text { Presentation } \\
\text { Class participation } \\
\text { Final paper/report }\end{array}$ & $\begin{array}{l}\text { Presentations } \\
\text { Class participation } \\
\text { Final paper/report } \\
\text { Reflection journals }\end{array}$ \\
\hline \multicolumn{7}{|l|}{$\begin{array}{l}\text { 7. Assessment } \\
\text { and Evaluation }\end{array}$} \\
\hline & Unclear & $\begin{array}{l}\text { Formal } \\
\text { feedback from } \\
\text { participants } \\
\end{array}$ & $\begin{array}{l}\text { Accreditation - } \\
\text { Graduate attribute } \\
\text { assessment }\end{array}$ & $\begin{array}{l}\text { Accreditation - Graduate } \\
\text { attribute assessment }\end{array}$ & Unclear & $\begin{array}{l}\text { Formal feedback } \\
\text { gathered from } \\
\text { participants } \\
\end{array}$ \\
\hline
\end{tabular}

